\title{
Requirements of Energy and Protein for Arabic Chicken During Early Egg Production
}

\author{
Syafwan* \& Noferdiman \\ Faculty of Animal Science, University of Jambi \\ Jalan Raya Jambi-Ma. Bulian KM. 15 Mendalo Darat, Jambi, 36361, Indonesia \\ ${ }^{*}$ Corresponding author: syafwan@unja.ac.id \\ (Received 14-04-2020; Revised 05-07-2020; Accepted 15-07-2020)
}

\begin{abstract}
The objectives of this experiment were to calculate energy (ME) and crude protein $(\mathrm{CP})$ requirements of Arabic chicken hens in the tropical climates during the early laying period by a choice feeding method. One hundred and thirty-eight of 22-week old Arabic chicken hens were allotted into 12 sheltered pens with 10-14 chicks each. The no free-choice group hens fed a standard diet conforming with the Hy-line Brown Commercial Management Guide, whilst the free-choice group hens fed with a standard diet, an energy-protein rich diet, an energy-rich diet, a protein-rich diet, and an energy-protein poor diet. Feed consumption, energy and protein consumptions, energy ( $\mathrm{kcal}$ of ME/kg) and protein (g of $\mathrm{CP} / \mathrm{kg}$ ) dietary concentrations were recorded weekly, and egg production was recorded daily. All performance data were taken repeatedly during the first 28 weeks of egg production and were analyzed after summarizing weekly data into seven 28 -d periods using the Mixed Procedure in SAS. The dietary treatments had no clear effect on feed and protein consumption but had a significant effect on energy consumption, energy and protein concentrations, and egg production. Energy consumption of the no free-choice group hens was lower than those in the free-choice group hens (1580 vs. $1718 \mathrm{kcal}$ of ME/ $\mathrm{kg} / \mathrm{hen} ; \mathrm{p}<0.05)$. Energy and protein concentration in the diet of the no free-choice group hens were lower $(\mathrm{p}<0.01)$ than those in the free-choice group hens ( $2814 \mathrm{vs} .3050 \mathrm{kcal} \mathrm{of} \mathrm{ME} / \mathrm{kg}$ and $184 \mathrm{vs} .189 \mathrm{~g}$ of $\mathrm{CP} / \mathrm{kg}$, respectively). The no free-choice group produced less egg $(\mathrm{p}<0.01)$ than those of the free-choice group $(56 \%$ vs. $61 \%)$. Arabic chicken hens consumed more feed from an energy-protein rich diet and an energy-rich diet and consumed less feed from a protein-rich diet and an energy-protein poor diet. Based on the choice feeding, ME and $\mathrm{CP}$ requirements for Arabic chicken hens during early egg production were higher than ME and CP contained in the control diet. An average hen day production was higher in the free choice group compared to the control diet group.
\end{abstract}

Keywords: choice feeding; Arabic chicken hens; energy and protein; egg production; tropical climates

\section{INTRODUCTION}

Arabic chicken as a local chicken which is considered as one of the local chicken strains claimed in Indonesia has been driven to meet the demand need of poultry egg because this hen has been producing more egg (Hartawan \& Dharmayanti, 2016). Directorate General of Livestock and Animal Health, Ministry of Agriculture of the Republic of Indonesia (2019) reported that the national egg production was contributed largely by the commercial layer chicken by $88.99 \%$ and native chickens contributed only $4.03 \%$. Therefore, the potential of Arabic chicken hens to produce more egg should be improved.

Nutrient requirements for Arabic chicken hens during any production phase are one of the most important factors affecting egg production and have been investigating by some researchers (Mulyadi, 2013; Alwi et al., 2019). Therefore, the feeding standard of NRC (1994) or of Hy-line Brown Commercial Management Guide (2011) was applied to formulate the ration with high consideration. The feeding standard for commercial chicken under non-tropical climate conditions might not be appropriate for Arabic chicken hens under the tropical climate conditions. The daily high temperature in the tropic regions will induce heat stress and consequently influence some number of physiological consequences including the decline in feed intake, protein and energy intakes, body weight gain, rise in body temperature in broiler (Syafwan et al., 2012), and decrease egg production in layer (Barrett et al., 2019; Castro et al., 2019).

Egg production of local chickens can be increased by increasing the protein level in the diet. Local hens fed a diet composing of $16 \%-17.5 \%$ crude protein $(\mathrm{CP})$ and $2800 \mathrm{kcal}$ metabolizable energy (ME)/kg produced $41 \%$ hen-day production (HP) egg (Khawajaa et al., 2012) and a diet composing of $18.4 \% \mathrm{CP}$ and $2750 \mathrm{kcal}$ of $\mathrm{ME} / \mathrm{kg}$ produced 58\% HP egg (Adrizal et al., 2011). The increase in egg production from previous trials used an intensive rearing system and not a semi-scavenging rearing system and using a fixed ME (2759 kcal of ME/kg) and CP $(18.4 \%)$. 
Another way to get the appropriate value of ME and $\mathrm{CP}$ requirements for laying hens in the tropics is a free choice feeding strategy. A free choice feeding strategy permits the hens to choose their own dietary compositions associated with their physiological and environmental conditions. In male broilers, offering a free choice feeding under high temperature were able to select a diet to reduce the adverse effect of heat stress on BW gain (Syafwan et al., 2012). In laying hens, egg production, egg mass, and feed efficiency were higher when offered free choices diet that included diets supplemented with fat and with a high energy (2980 $\mathrm{kcal} / \mathrm{kg}$ ) and protein $(17 \%)$ compared with low energy $(2800 \mathrm{kcal} / \mathrm{kg})$ and protein $(16 \%)$ in the diet at hot environmental temperature (Daghir, 2008). It is of interest to know what kind of diet the Arabic chicken hens would select from various qualities of diets to compose their nutrient requirements that suitable with their egg production capacities. This selection may result in a better egg production compared with a control diet.

The objectives of the present study were (1) to test the hypothesis that Arabic chicken hens at the age of early laying period had an ability to compose satisfactory nutrients from different qualities of diets with a choice feeding and (2) to determine whether layers fed by free choice would consume and subsequently respond to the increasing levels of dietary energy and protein compared to a standard layer ration, and (3) to compare the egg production of Arabic chicken hens when given a free choice diet with a control diet.

\section{MATERIALS AND METHODS}

\section{Animal Care, Birds, and Housing}

One hundred and thirty-eight 22 weeks of age of Arabic chicken hens (Hartawan \& Dharmayanti, 2016) were used in this research. The experimental hens were continued from the trial of one to 22 weeks of age and stayed in the same allocated of 12 pens, each with 10-14 hens. Arabic chicken hens did not lay egg yet until the end of the pre-laying age of 17 weeks. To be saved, a laying diet was offered from 18 weeks to 50 weeks of age. The dietary treatments were the same as this experiment, except the control diet was changed on 18 weeks of age to a laying diet. In this experiment, the $10 \%$ egg production started at 22 weeks of age in both treatments and started to record the parameters measured. Each pen dimension was $2 \mathrm{~m}$ inside the house and $3 \mathrm{~m}$ outside the house for scavenging area with similar width $(1.75 \mathrm{~m})$ and height $(2 \mathrm{~m})$. The pen was separated with netted nylon. The pen floor inside the house was covered with sand, and the pen floor outside the house was ground. The house was an opensided house and the hens could access to the yard freely.

Each diet was served in separate feed troughs in each pen. One bell-shaped drinker was used for drinking water and the wooden perch about $1 \mathrm{~m}$ height upon the floor and nest in each pen were provided.

Daily ambient temperature (Ta) and relative humidity (RH) were recorded at 07:00 am, 12:00, and 17:00 pm by using thermo-hygrometer. An emergency light was placed for every two pens to guarantee 16-hour light and 8-hour dark every day when the electric went off.

\section{Experimental Design and Treatments}

A completely randomized design with two treatments and six replicates (pens) were used in this experiment. The no free-choice groups fed a standard diet, as suggested by The Hy-line Brown Commercial Management Guide (HyLine, 2011), for the early laying phase [18 to 50 weeks of age] containing $2814 \mathrm{kcal}$ of $\mathrm{ME} / \mathrm{kg}$ and $18.4 \%$ of CP. The free-choice groups were fed (1) a standard diet; (2) an energy-protein rich diet, EPRD [ME:3101 kcal/kg and CP:23.0\%], (3) an energyrich diet, ERD [ME:3133 kcal/kg and CP:14.3\%], (4) a protein-rich diet, PRD [ME:2638 kcal/kg and CP:23.4\%], and (5) an energy-protein poor diet, EPPD [ME:2677 $\mathrm{kcal} / \mathrm{kg}$ and CP:14.6\%]. Each diet was supplied as a mash form in separate feeders to 50 weeks of age ad libitum. The site of each feeder in pen was changed randomly every day to avoid the habituation of the hens about the place of the diets. Dietary compositions and the nutrients content of the diets are presented in Table 1 and Table 2, respectively. These four diets differed from that of the control in the energy and protein contents, while the other nutrients were almost identical.

\section{Traits Measured}

Feed consumption (FC) per pen was recorded weekly by weighing the feed offered and feed residues on a weekly basis (g/bird/week). Weekly energy and protein consumption were calculated from the consumption of each of the five diets. The concentrations of energy and protein consumption were calculated from the energy and protein consumptions with the concentrations of each diet (Syafwan et al., 2012). Egg production was recorded daily begun when the hens laid the egg at least $10 \%$ hen day production (HDP). The percentage of hen day egg production (\% HDP) was calculated from the total number of eggs laid divided by the total number of live hen per day (Khawajaa et al., 2012).

\section{Statistical Analysis}

All performance data were taken repeatedly during the first 28 weeks of egg production for each experimental unit. Therefore, the covariance structure among repeated observations was considered and determined with a mixed model (Littell et al., 1998; Walter et al., 2018). Data were analyzed after summarizing weekly data into seven 28 -d periods. A p-value of $\leq 0.05$ was considered for significant differences among the treatments and least squares mean comparison was used to compare the means. The denominator $\mathrm{df}$ for the tests of main effects was computed with the Kenward-Roger method. The corrected Akaike Information Criteria (AICC) was used 
Table 1 . The ingredients $(\mathrm{g} / \mathrm{kg})$ composition of dietary treatments

\begin{tabular}{lccccc}
\hline \multicolumn{1}{c}{ Ingredients } & $\begin{array}{c}\text { Standard diet } \\
\text { (18 to 50 week) }\end{array}$ & $\begin{array}{c}\text { Energy-protein } \\
\text { rich diet (EPRD) }\end{array}$ & $\begin{array}{c}\text { Energy rich diet } \\
\text { (ERD) }\end{array}$ & $\begin{array}{c}\text { Protein rich diet } \\
\text { (PRD) }\end{array}$ & $\begin{array}{c}\text { Energy-protein } \\
\text { poor diet (EPPD) }\end{array}$ \\
\hline Rice bran & 160.00 & 0.00 & 174.00 & 243.00 & 366.00 \\
Maize & 320.00 & 433.00 & 550.00 & 287.00 & 360.00 \\
Soybean meal & 251.50 & 355.00 & 130.00 & 405.00 & 200.00 \\
Fish meal & 82.00 & 90.00 & 50.00 & 40.00 & 0.00 \\
Salt & 3.00 & 2.00 & 2.00 & 2.00 & 3.00 \\
Top mix ${ }^{1}$ & 5.00 & 5.00 & 5.00 & 5.00 & 5.00 \\
Dicalcium phosphate & 2.00 & 0.00 & 3.00 & 3.00 & 12.00 \\
Calcium carbonate & 95.00 & 15.00 & 20.00 & 15.00 & 50.00 \\
DL-Methionine & 1.50 & 0.00 & 2.00 & 0.00 & 2.00 \\
L-lysine HCL & 0.00 & 0.00 & 4.00 & 0.00 & 0.00 \\
Palm oil & 80.00 & 100.00 & 60.00 & 0.00 & 0.00 \\
\hline
\end{tabular}

Note: ${ }^{1}$ Composition of $1 \mathrm{~kg}$ Top Mix: vitamin A (retinyl acetate), 12,000 IU; vitamin D3 (cholecalciferol), 2,000 IU; vitamin E (dl- $\alpha$-tocopherol), 8.0 mg vitamin $\mathrm{K}, 2.0 \mathrm{mg}$; vitamin B1 (thiamin), $2.0 \mathrm{mg}$; vitamin B2 (riboflavin), $5.0 \mathrm{mg}$; vitamin B6 (pyridoxine- $\mathrm{HCl}$ ), $0.5 \mathrm{mg}$, vitamin B12 (cyanocobala$\mathrm{min}$ ), $12 \mathrm{mg}$; vitamin C, $25 \mathrm{mg}$; niacin, $40 \mathrm{mg}$; vitamin B5 (d-pantothenic acid), $6.0 \mathrm{mg}$; choline chloride, $10 \mathrm{mg}$; methionine, $30 \mathrm{mg}$; lysine, $30 \mathrm{mg}$; iron, $20 \mathrm{mg}$; copper, $4 \mathrm{mg}$; manganese, $120 \mathrm{mg}$; zinc, $100 \mathrm{mg}$; cobalt, $0.2 \mathrm{mg}$; iodine, 0.2; zinc bacitracin, $21 \mathrm{mg}$ and santoquin (antioxidant), $10 \mathrm{mg}$.

Table 2. Calculated nutrients content $(/ \mathrm{kg})$ of dietary treatments

\begin{tabular}{lccrrr}
\hline \multicolumn{1}{c}{ Nutrients } & $\begin{array}{c}\text { Standard diet } \\
(18 \text { to 50 week) }\end{array}$ & $\begin{array}{c}\text { Energy-protein } \\
\text { rich diet (EPRD) }\end{array}$ & $\begin{array}{r}\text { Energy rich diet } \\
\text { (ERD) }\end{array}$ & $\begin{array}{r}\text { Protein rich diet } \\
\text { (PRD) }\end{array}$ & $\begin{array}{r}\text { Energy-protein } \\
\text { poor diet (EPPD) }\end{array}$ \\
\hline Dry matter (\%) & 71.20 & 76.50 & 78.60 & 85.40 & 81.00 \\
Crude protein (\%) & 18.40 & 23.00 & 14.30 & 23.40 & 14.60 \\
ME (kcal/kg) & 2814.00 & 3101.00 & 3133.00 & 2638.00 & 2677.00 \\
Crude fat (\%) & 4.56 & 1.77 & 4.74 & 6.68 & 8.61 \\
Crude fiber (\%) & 4.11 & 3.90 & 4.65 & 4.53 & 4.77 \\
Lysine (\%) & 1.28 & 1.56 & 1.24 & 1.53 & 1.03 \\
Methionine (\%) & 0.56 & 0.48 & 0.52 & 0.45 & 0.47 \\
Met+Cys (\%) & 0.88 & 0.87 & 0.78 & 0.86 & 0.76 \\
Calcium (\%) & 4.24 & 1.06 & 1.11 & 0.95 & 2.31 \\
Total P (\%) & 0.79 & 0.62 & 0.76 & 0.93 & 1.10 \\
NPP (\%) & 0.46 & 0.45 & 0.35 & 0.39 & 0.41 \\
Na (\%) & 0.19 & 0.15 & 0.14 & 0.13 & 0.15 \\
\hline
\end{tabular}

Note: ${ }^{1}$ Metabolizable energy (ME) was calculated by determining (combustion) gross energy of the entire diet multiplied with a ME/GE-conversion factor (0.725).

to choose the best covariance structure. The Compound Symmetry covariance structure (CS) fits the data best for FC, energy, and protein consumptions. The autoregressive covariance structure $[\mathrm{AR}(1)]$ fits the data best for the concentration of protein. The heterogeneous autoregressive covariance structure [ARH(1)] fits the data best for the concentration of energy. The simple covariance structure fits the data best for egg production.

\section{RESULTS}

\section{Ambient Temperature and Humidity}

Ambient temperature (Ta) and humidity ( $\mathrm{RH}$ ) are presented as the average \pm SD for each time recorded. $\mathrm{Ta}$ and $\mathrm{RH}$ in the morning (07.00) were $24.23 \pm 1.02^{\circ} \mathrm{C}$ and $77 \pm 4.43 \%$. In the day (12.00), Ta and $\mathrm{RH}$ were $31.18 \pm 1.81^{\circ} \mathrm{C}$ and $51 \pm 6.34 \%$, while in the afternoon (17.00), Ta and $\mathrm{RH}$ were $29.97 \pm 2.12^{\circ} \mathrm{C}$ and $56 \pm 9.72 \%$.

\section{Hens Performance}

Table 3 presents the probability values for all parameters and Table 4 shows the performance of the Arabic chicken hens at different dietary treatments periodically. Dietary treatments had no effect on feed consumption (FC) and protein consumption of the hens (Table 3), although fluctuation was observed in FC and protein consumption (PC) for some periods. FC and PC of choice-fed hens below and above the no-choice-fed hens during 2 and 6 periods, respectively (Table 4). Feeding methods affected energy consumption, energy and protein concentrations, and egg production (Table $3)$. Energy consumption $(\mathrm{p}<0.05)$, energy and protein concentrations $(\mathrm{p}<0.001)$, and egg production $(\mathrm{p}<0.05)$ were higher in the choice-fed hens. All parameters measured were affected by period (Table 3). FC, PC, and protein concentration were higher in the $2^{\text {nd }}$ period, slowly reduced until the $6^{\text {th }}$ period, and increased in the $7^{\text {th }}$ period. Energy intake and protein concentration were higher in the $1^{\text {st }}$ period, fluctuated until the $6^{\text {th }}$ period, 
Table 3. Probability values ${ }^{1}$ of main effects and interaction between dietary treatment ${ }^{2}(\mathrm{~F})$ and period for different traits

\begin{tabular}{lcccccc}
\hline Main Effect & $\begin{array}{c}\text { Feed } \\
\text { consumption } \\
\text { (g/hen/period) }\end{array}$ & $\begin{array}{c}\text { Protein } \\
\text { consumption } \\
\text { (g of CP/hen/ } \\
\text { period) }\end{array}$ & $\begin{array}{c}\text { Energy } \\
\text { consumption } \\
\text { (kcal of ME/kg/ } \\
\text { hen/period) }\end{array}$ & $\begin{array}{c}\text { Protein } \\
\text { concentration } \\
\text { (g of CP/kg) }\end{array}$ & $\begin{array}{c}\text { Energy } \\
\text { concentration } \\
(\text { kcal of ME/kg) }\end{array}$ & $\begin{array}{c}\text { Egg production } \\
(\%)\end{array}$ \\
\hline No choice diet & 561 & 103 & 1580 & 184 & 2814 & 55 \\
Choice diet & 563 & 106 & 1718 & 189 & 3050 & 61 \\
F & 0.903 & 0.147 & $<.05$ & $<.001$ & $<.001$ & $<.001$ \\
Period & $<.001$ & $<.001$ & $<.001$ & $<.001$ & $<.001$ & $<.001$ \\
F Period $^{3}$ & $<.001$ & $<.001$ & $<.001$ & $<.001$ & $<.001$ & 0.999 \\
\hline
\end{tabular}

Note: ${ }^{1}$ Probability values with boldface differ significantly $(\mathrm{p} \leq 0.05)$.

${ }^{2}$ No-choice: Standard diet (ME: 2814 kcal/kg and CP: 18.4\%); Choice: 1. Standard diet (ME: 2814 kcal $/ \mathrm{kg}$ and CP: 18.4\%); 2. energy-protein rich $\operatorname{diet}($ EPRD) (ME:3101 kcal/kg and CP:23.0\%); 3. energy rich diet (ERD)(ME:3133 kcal $/ \mathrm{kg}$ and CP:14.3\%); 4. protein rich diet (PRD) (ME:2638 kcal/ $\mathrm{kg}$ and CP:23.4\%); 5. energy-protein poor diet (EPPD) (ME:2677 kcal/kg and CP:14.6\%).

${ }^{3} \mathrm{~F} \times$ Period (interaction between dietary treatment and period).

Table 4. Least square means of performance variables in Arabic chicken hens as affected by dietary treatments

\begin{tabular}{|c|c|c|c|c|c|c|c|c|}
\hline \multirow{2}{*}{ Variables } & \multicolumn{7}{|c|}{ Period } & \multirow{2}{*}{ Average } \\
\hline & 1 & 2 & 3 & 4 & 5 & 6 & 7 & \\
\hline \multicolumn{9}{|c|}{ Feed consumption (g/hen/period) } \\
\hline No choice & 579.45 & 655.76 & 562.84 & 564.79 & 542.83 & 459.47 & 566.36 & 561.64 \\
\hline Choice & 568.67 & 576.09 & 579.99 & 559.76 & 507.99 & 574.94 & 576.50 & 563.42 \\
\hline SEM & 21.22 & 21.22 & 21.22 & 21.22 & 21.22 & 21.22 & 21.22 & 13.20 \\
\hline Probability & 0.72 & 0.01 & 0.57 & 0.87 & 0.252 & $<0.001$ & 0.74 & 0.93 \\
\hline \multicolumn{9}{|c|}{ Protein consumption ( $\mathrm{g}$ of $\mathrm{CP} /$ hen/period) } \\
\hline No choice & 106.54 & 120.57 & 103.49 & 103.84 & 99.81 & 84.48 & 104.13 & 103.26 \\
\hline Choice & 106.75 & 110.70 & 109.20 & 107.23 & 94.90 & 106.23 & 110.62 & 106.52 \\
\hline SEM & 3.93 & 3.93 & 3.93 & 3.93 & 3.93 & 3.93 & 3.93 & 2.42 \\
\hline Probability & 0.97 & 0.08 & 0.31 & 0.55 & 0.38 & $<0.001$ & 0.25 & 0.36 \\
\hline \multicolumn{9}{|c|}{ Energy consumption ( $\mathrm{kcal}$ of ME/kg/hen/period) } \\
\hline No choice & 1630.61 & 1845.38 & 1583.89 & 1589.36 & 1527.57 & 1292.99 & 1593.78 & 1580.51 \\
\hline Choice & 1749.05 & 1761.56 & 1759.03 & 1712.30 & 1543.61 & 1738.58 & 1760.99 & 1717.87 \\
\hline SEM & 62.52 & 62.52 & 62.52 & 62.52 & 62.52 & 62.52 & 62.52 & 39.42 \\
\hline Probability & $<0.001$ & 0.35 & 0.05 & 0.17 & 0.86 & $<0.001$ & 0.06 & 0.03 \\
\hline \multicolumn{9}{|c|}{ Protein concentration ( $\mathrm{g}$ of $\mathrm{CP} / \mathrm{kg}$ ) } \\
\hline No choice & 183.86 & 183.86 & 183.86 & 183.86 & 183.86 & 183.86 & 183.86 & 183.86 \\
\hline Choice & 187.73 & 192.84 & 188.29 & 191.94 & 186.31 & 184.92 & 191.87 & 189.13 \\
\hline SEM & 0.33 & 0.90 & 0.52 & 1.07 & 1.11 & 0.88 & 0.30 & 0.26 \\
\hline Probability & $<0.001$ & $<0.001$ & $<0.001$ & $<0.001$ & 0.15 & 0.42 & $<0.001$ & $<0.001$ \\
\hline \multicolumn{9}{|c|}{ Energy concentration (kcal of ME/kg) } \\
\hline No choice & 2814.09 & 2814.09 & 2814.09 & 2814.09 & 2814.09 & 2814.09 & 2814.09 & 2814.09 \\
\hline Choice & 3074.43 & 3056.84 & 3033.27 & 3060.34 & 3043.47 & 3026.66 & 3054.56 & 3049.94 \\
\hline SEM & 3.75 & 3.75 & 3.75 & 3.75 & 3.75 & 3.75 & 3.75 & 1.98 \\
\hline Probability & $<0.001$ & $<0.001$ & $<0.001$ & $<0.001$ & $<0.001$ & $<0.001$ & $<0.001$ & $<0.001$ \\
\hline \multicolumn{9}{|c|}{ Egg production (\%/hen/period) } \\
\hline No choice & 39.3 & 67.1 & 53.1 & 56.9 & 58.8 & 54.5 & 56.1 & 55.09 \\
\hline Choice & 44.5 & 69.1 & 57.3 & 63.8 & 62.8 & 61.9 & 65.0 & 60.64 \\
\hline SEM & 3.57 & 3.57 & 3.57 & 3.57 & 3.57 & 3.57 & 3.57 & 1.35 \\
\hline Probability & 0.30 & 0.68 & 0.41 & 0.17 & 0.42 & 0.15 & 0.08 & 0.005 \\
\hline
\end{tabular}

Note: Means within a period between treatments with boldface probability value differ significantly ( $\mathrm{p} \leq 0.05)$. No-choice: Standard diet (ME: 2814 $\mathrm{kcal} / \mathrm{kg}$ and CP: $18.4 \%$ ) Choice: 1 . Standard $\operatorname{diet}(\mathrm{ME}: 2814 \mathrm{kcal} / \mathrm{kg}$ and CP: 18.4\%); 2. energy-protein rich diet (EPRD) (ME: $3101 \mathrm{kcal} / \mathrm{kg}$ and CP: 23.0\%); 3. energy rich diet (ERD) (ME: $3133 \mathrm{kcal} / \mathrm{kg}$ and CP: 14.3\%); 4. protein rich diet (PRD) (ME: $2638 \mathrm{kcal} / \mathrm{kg}$ and CP: 23.4\%); and 5. energyprotein poor diet (EPPD) (ME: $2677 \mathrm{kcal} / \mathrm{kg}$ and CP: $14.6 \%)$. 
and increased again in the $7^{\text {th }}$ period. Egg production increased in the $2^{\text {nd }}$ period and remain constant between the $3^{\text {rd }}$ to $7^{\text {th }}$ periods (Figure 1 ). There were interaction effects between dietary treatments and period on FC, protein consumption, energy consumption, as well as protein and energy concentrations (Table 3). An interaction showed that FC, protein consumption, and energy consumption were higher in the $2^{\text {nd }}$ period and were lower in the $6^{\text {th }}$ period in the no-choice-fed hens. Protein concentration was higher in almost all of the periods in choice-fed hens, while energy concentration was higher in hens given a choice that was above hens given a standard diet in all periods (Figure 2).

\section{DISCUSSION}

Diurnal temperatures rhythm in the house in this study expressed the regular daily climates because no intervention was taken to control the temperatures. The increase of Ta was followed by the decrease of $\mathrm{RH}$ and vice versa. This daily temperature rhythm might helpful for the hens to control body temperature by releasing the body heat to the environment whenever the temperature was not comfortable. We observed that the birds were panting when the temperature raised above $28^{\circ} \mathrm{C}$ and it depicted that the temperature was above the normal range for them. Therefore, the environmental temperature conditions indicate that the hens experienced heat stress during the hot time period of the day because panting is one of the indicators of heat stress (Khoddami et al., 2018).

Feed consumption was similar between choice-fed and no choice-fed hens. Feed consumption results in this study are in agreement with the observation in broiler chicken under high temperature (Syafwan et al., 2012). Although feed consumption was similar with the no choice-fed group, the choice-fed group liked more to consume feed from a higher energy diet $(43.27 \%$ from EPRD and $36.09 \%$ from ERD) by reducing the consumption of a protein-rich diet and energy-protein poor diet (Figure 3). The preference of the Arabic chicken hens to consume a high-energy diet suggested that energy requirement under high environmental temperature was high to release the body heat temperature. In contrast, the low preference to a protein-rich diet aimed to avoid the increased body temperature from high heat increment of protein metabolism. These preferences agree with the other choice feeding study under the high temperature that the bird chose more from the energyrich diet than that of the protein-rich diet (Syafwan et
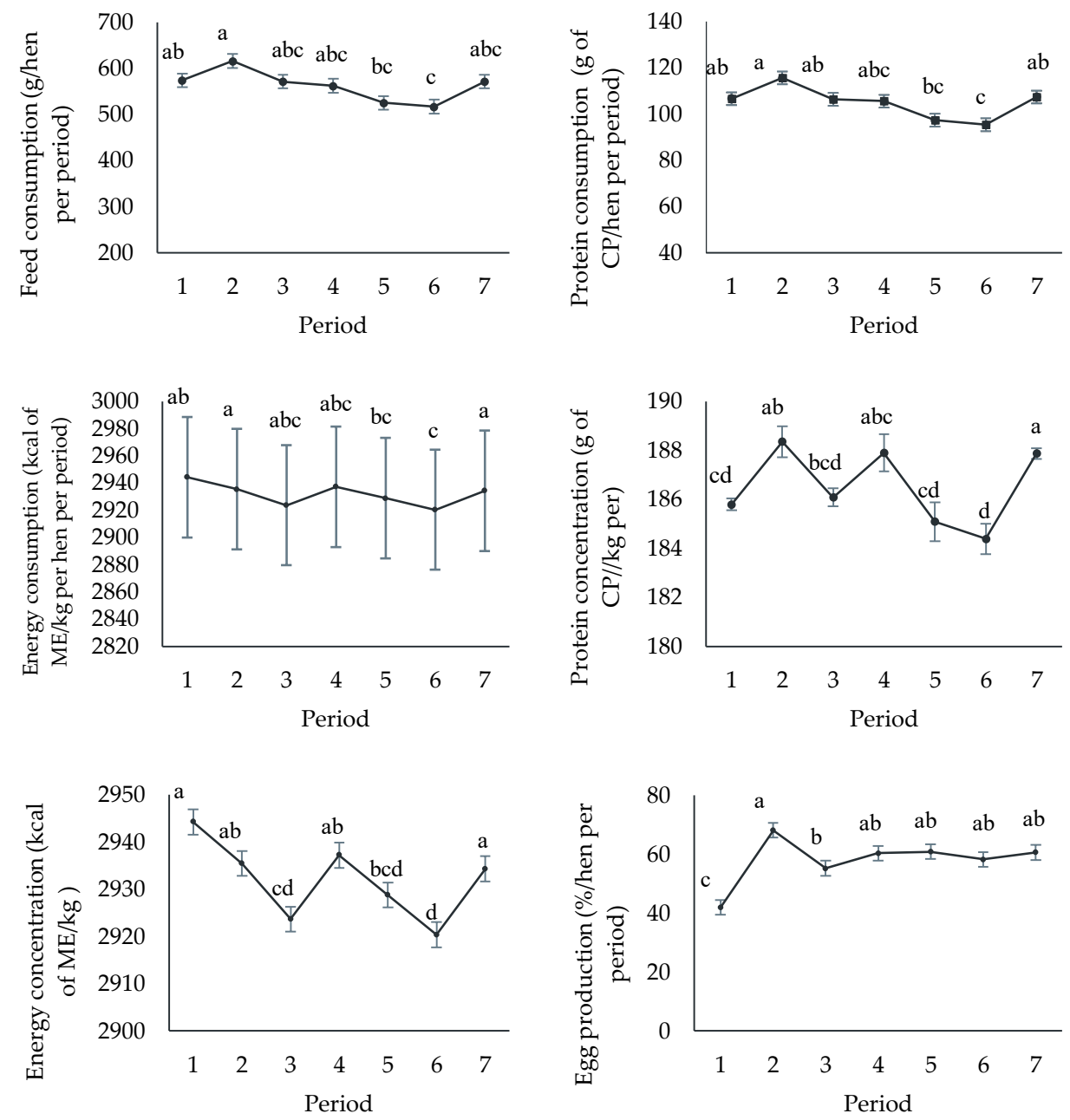

Figure 1. Least square means for traits that shows a significant period effect. Means within lines without common letters ( $a-d)$ differ significantly $(p \leq 0.05)$. 

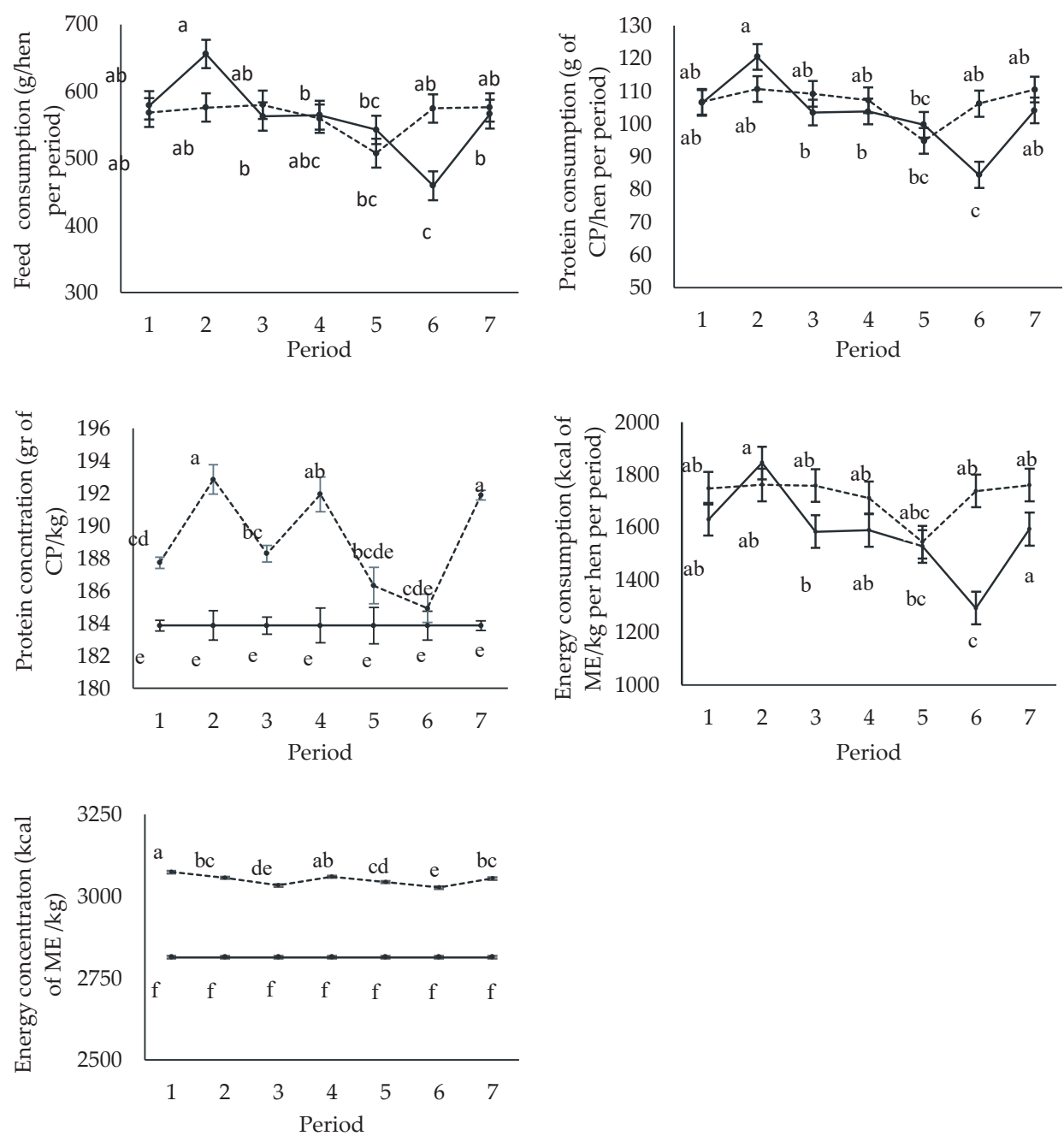

Figure 2. Least square means for traits that show a significant dietary treatment and period interaction. Means within and between lines without common letters $(a-f)$ differ significantly $(\mathrm{p} \leq 0.05)$. No-choice: Standard diet (ME: $2814 \mathrm{kcal} / \mathrm{kg}$ and CP: 18.4\%) Choice: 1. Standard diet (ME: $2814 \mathrm{kcal} / \mathrm{kg}$ and CP: 18.4\%); 2. energy-protein rich diet (EPRD) (ME: $3101 \mathrm{kcal} / \mathrm{kg}$ and CP: 23.0\%); 3. energy rich diet (ERD) (ME: $3133 \mathrm{kcal} / \mathrm{kg}$ and CP: $14.3 \%$ ); 4. protein rich diet (PRD) (ME: $2638 \mathrm{kcal} / \mathrm{kg}$ and CP: 23.4\%); and 5. energy-protein poor diet (EPPD) (ME: $2677 \mathrm{kcal} / \mathrm{kg}$ and CP: 14.6\%). No choice $=$ - - , choice $=--\bullet--$

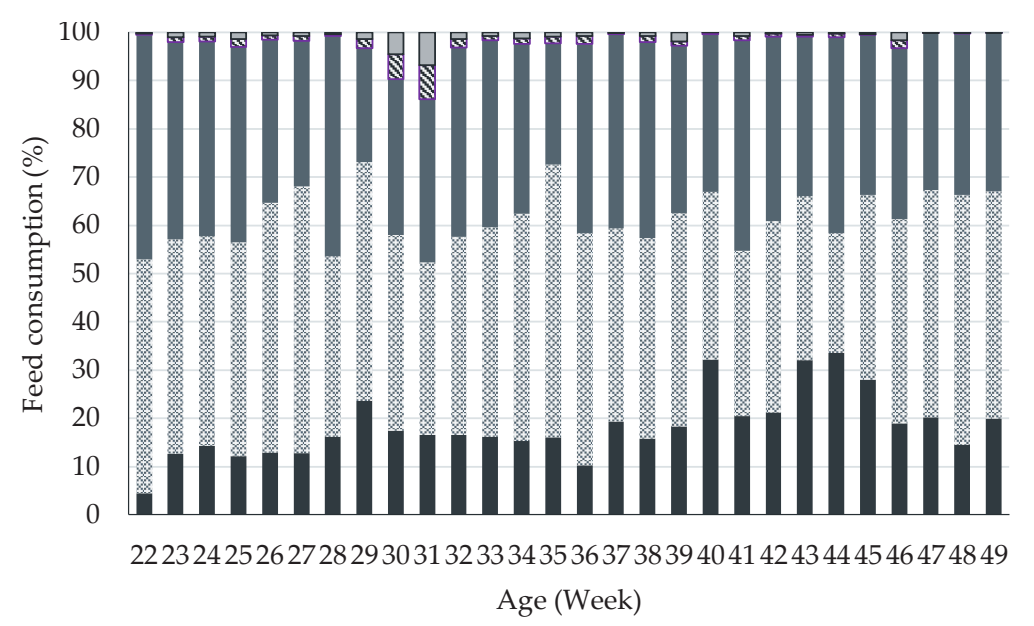

Figure 3. Consumption of a standard diet, energy-protein rich diet (EPRD), energy rich diet (ERD), protein rich diet (PRD) and energy-protein poor diet (EPPD) as a proportion of total feed intake ${ }^{1}$.

${ }^{1}$ Standard diet (匹, ME: $2814 \mathrm{kcal} / \mathrm{kg}$ and CP: 18.4\%); energy-protein rich diet (EPRD, 象) (ME: $3101 \mathrm{kcal} / \mathrm{kg}$ and CP: 23.0\%); energy rich diet (ERD, $\square$ ) (ME: $3133 \mathrm{kcal} / \mathrm{kg}$ and CP: $14.3 \%)$; protein rich diet (PRD, 圈) (ME: $2638 \mathrm{kcal} / \mathrm{kg}$ and CP: 23.4\%); and energy-protein poor diet (EPPD, $\square$ ) (ME: $2677 \mathrm{kcal} / \mathrm{kg}$ and CP: 14.6\%). 
al., 2012). Feed intake and egg production of laying hens were negatively affected by high ambient temperatures (Deng et al., 2012).

The average energy consumption in the hens offered the free-choice diet were higher than those provided by the standard diet $(1715.6 \mathrm{kcal}$ vs. $1578.0 \mathrm{kcal}$ of $\mathrm{ME} /$ hens; $\mathrm{p}<0.001)$. This distinct preference suggests that Arabic chicken hens can adjust their nutrients requirements from different diet contents independently. Finetuning energy and protein requirements in laying hens were reported by Molnar et al. (2018) that egg production was similar in the conventional diet $(2794 \mathrm{kcal} / \mathrm{kg}$, $17.1 \% \mathrm{CP}, 3 \% \mathrm{Ca}$ ) when offered high energy, high protein and low Ca diet, low energy, and low protein high Ca diet simultaneously (3065 kcal $/ \mathrm{kg} ; 19.2 \% \mathrm{CP}, 0.47 \%$ $\mathrm{Ca}, 1740 \mathrm{kcal} / \mathrm{kg}$; and $10.7 \% \mathrm{CP}, 13.1 \% \mathrm{Ca}$, respectively). In broiler, the live weight of broiler given low protein ingredients but allowed to scavenging were equal with chicken fed with $20 \% \mathrm{CP}$ at the end of the study. It is possible that additional protein is obtained by free range chicken from forage plants, depending on forage quality, as well as live protein, such as insects and annelids (Fanatico et al., 2013).

The preferences of the hens to choose diet were as follows EPRD diet (43.11\%), ERD diet (36.30\%), standard diet $(18.28 \%)$, PRD diet $(1.23 \%)$, and EPPD diet (1.08\%) (Figure 3). Based on these choices, energy and protein concentration in the diet consumed were significantly higher in the choice group (Figure 2). The higher energy and protein concentration demonstrated that the choice feeding permits the possibility to regulate its energy and protein need during early egg production (3050 vs. $2814 \mathrm{kcal}$ of $\mathrm{ME} / \mathrm{kg}$; $\mathrm{p}<0.001 ; 189$ vs. $184 \mathrm{~g}$ of $\mathrm{CP} / \mathrm{kg} ; \mathrm{p}<0.001)$.

The higher energy and protein concentrations in the diet composed by the hens given a choice show that hens were capable of choosing a diet that contains nutrients for their needs. The capability of broiler to adjust their energy and protein requirements by selecting several diets have reported by Syafwan et al. (2012). These results suggest that energy and protein needs for Arabic chicken hens during the early production phase probably higher than the energy and protein in the control diet. The higher energy requirement of Arabic chicken hens in this study was more likely due to the hens had free access to walk in and out to the scavenging area and to release body heat. They also need more protein and energy to produce more eggs. The higher energy concentration in the feed selected by Arabic chicken given a choice indicates the higher hen's energy requirements in the tropical environment. This higher energy concentration under high temperature reflects the higher demand of energy to release the heat load (Daghir, 2008). On the other hand, an energy-rich diet may be favorable for the hens than a protein-rich diet under high environmental temperature because protein produces more heat load per kilojoules than do fat and carbohydrate (Daghir, 2008; Syafwan et al., 2011). The common practice to use of high-energy layer ration in hot climates nowadays is due to not only improves feed intake but also improves egg production, egg mass, egg weight, and shell thickness (Daghir, 2008). Alwi et al. (2019) reported that feed consumption and egg production of Arabic chicken was higher with high energy (2800 kcal ME/kg) and high protein (18\%) diet than 2500 to $2700 \mathrm{kcal}$ of $\mathrm{ME} / \mathrm{kg}$ and 15 to $17 \%$ of CP diet.

The hens given the free-choice diet produced more egg from the beginning of production at 21 weeks of age. At this age, hens in two experimental units from no choice-fed group did not lay (5\% in total). Meanwhile, eggs were produced from all unit experiments of the choice-fed group ( $8 \%$ in total). Therefore, choice-fed birds laid an egg earlier than no choice-fed birds. The more egg produced by hens given the free-choice diet from 1 to 7 periods could be due to the higher protein concentration in the diet composed by the hens. Information about the response of laying hens' given with choice feeding under high-temperature conditions is limited. In normal environmental conditions $\left(22^{\circ} \mathrm{C}\right)$, the commercial laying hens fed with a high protein $(21.62 \%)$ diet showed a higher body weight gain, feed consumption, and hen day egg production than that with medium $(19.62 \%)$ and low protein $(17.62 \%)$ diet for each egg production stage (Shim et al., 2013).

\section{CONCLUSION}

Arabic chicken hens were able to compose satisfactory nutrients from different qualities of diets to adjust their energy and protein requirements by increasing intake of an energy-protein rich diet and an energy-rich diet and reducing intake of a protein-rich diet and an energy-protein poor diet. Based on the free-choice feeding, ME and CP requirements for Arabic chicken hens during early egg production were higher than ME and $\mathrm{CP}$ contain in the control diet. An average hen day production was higher in the free choice $(61 \%)$ compared to the control diet (56\%).

\section{CONFLICT OF INTEREST}

We certify that there is no conflict of interest with any financial organization regarding the material discussed in the manuscript.

\section{ACKNOWLEDGEMENT}

The authors gratefully acknowledge funding of the University of Jambi. We also would like to thanks to Faculty of Animal Science, the University of Jambi to facilitate the experiment.

\section{REFERENCES}

Adrizal, A., Y. Yusrizal, S. Fakhri, W. Haris, E. Ali, \& R. C. Angel. 2011. Feeding native laying hens diets containing palm kernel meal with or without enzyme supplementations: 1. Feed conversion ratio and egg production. J. Appl. Poult. Res. 20:40-49. https://doi.org/10.3382/ japr.2010-00196

Alwi, W., L. Agustina, \& M. Z. Mide. 2019. Arabic chicken (Gallus turcicus) performance with different dietary energy-protein level. J. Sains dan Teknol. Peternak. 1:7-12. https://doi.org/10.31605/jstp.v1i1.422 
Barrett, N. W., K. Rowland, C. J. Schmidt, S. J. Lamont, M. F. Rothschild, C. M. Ashwell, \& M. E. Persia. 2019. Effects of acute and chronic heat stress on the performance, egg quality, body temperature, and blood gas parameters of laying hens. Poult. Sci. 98:6684-6692. https://doi.org/10.3382/ps/ pez541

Castro, F. L. S., H. Y. Kim, Y. G. Hong, \& W. K. Kim. 2019. The effect of total sulfur amino acid levels on growth performance, egg quality, and bone metabolism in laying hens subjected to high environmental temperature. Poult. Sci. 98:4982-4993. https://doi.org/10.3382/ps/pez275

Daghir, N. J. 2008. Replacement Pullet and Layer Feeding and Management in Hot Climates. p. 261-293 in Poultry Production in Hot Climates. Daghir, N.J., ed. $2^{\text {nd }}$ ed. CAB International, Cromwell Press, Trowbridge. https://doi. org/10.1079/9781845932589.0261

Deng, W., X. F. Dong, J. M. Tong, \& Q. Zhang. 2012. The probiotic Bacillus licheniformis ameliorates heat stress-induced impairment of egg production, gut morphology, and intestinal mucosal immunity in laying hens. Poult. Sci. 91:575582. https://doi.org/10.3382/ps.2010-01293

Director General of Livestock and Animal Health. 2019. Livestock and Animal Health Statistics. Director General of Livestock and Animal Health Service, Ministry of Agriculture, Jakarta.

Fanatico, A. C., V. B. Brewer, C. M. Owens-Hanning, D. J. Donoghue, \& A. M. Donoghue. 2013. Free-choice feeding of free-range meat chickens. J. Appl. Poult. Res. 22: 750758. https://doi.org/10.3382/japr.2012-00687

Hartawan, R., \& N. L. P. I. Dharmayanti. 2016. The Meq gene molecular profile of Marek's disease virus serotype 1 from Kampung and Arabic chicken farms in Sukabumi, West Java, Indonesia. HAYATI J. Biosci. 23:160-167. https://doi. org/10.1016/j.hjb.2016.12.004

HyLine. 2011. Hy-line Brown Commercial Management Guide. Hy-Line, Australia.

Khawajaa, T., S. H. Khanb, N. Mukhtara, M. A. Ali, T. Ahmed, \& A. Ghafar. 2012. Comparative study of growth performance, egg production, egg characteristics and haemato-biochemical parameters of Desi, Fayoumi and Rhode Island Red chicken. J. Appl. Anim. Res. 40: 273-283. https://doi.org/10.1080/09712119.2012.672310

Khoddami, A., P. V. Chrystal, P. H. Selle, \& S. Y. Liu. 2018. Dietary starch to lipid ratios influence growth performance, nutrient utilization and carcass traits in broiler chickens offered diets with different energy densities (C Óvilo, Ed.). PLoS One 13:e0205272. https://doi.org/10.1371/ journal.pone.0205272

Littell, R. C., P. R. Henry, \& C. B. Ammerman. 1998. Statistical analysis of repeated measures data using SAS procedures. J. Anim. Sci. 76:1216. https://doi.org/10.2527/1998.7641216x

Molnar, A., C. Hamelin, E. Delezie, \& Y. Nys. 2018. Sequential and choice feeding in laying hens: adapting nutrient supply to requirements during the egg formation cycle. Worlds. Poult. Sci. J. 74: 1-12. https://doi.org/10.1017/ S0043933918000247

Mulyadi, Y. 2013. The use of functional feed toward the performance of production and quality for Arabic chicken's eggs. J. Ilmu Ternak. 13: 27-33.

NRC. 1994. Nutrient Requirements of Poultry. $9^{\text {th }}$ rev.ed. National Academy Press, Washington, DC.

Shim, M. Y., E. Song, L. Billard, S. E. Aggrey, G. M. Pesti, \& P. Sodsee. 2013. Effects of balanced dietary protein levels on egg production and egg quality parameters of individual commercial layers. Poult. Sci. 92:2687-2696. https://doi. org/10.3382/ps.2012-02569

Syafwan, S., R. P. Kwakkel, \& M. W. A. Verstegen. 2011. Heat stress and feeding strategies in meat-type chickens. Worlds. Poult. Sci. J. 67:653-674. https://doi.org/10.1017/ S0043933911000742

Syafwan, S., G. J. D. Wermink, R. P. Kwakkel, \& M. W. A. Verstegen. 2012. Dietary self-selection by broilers at normal and high temperature changes feed intake behavior, nutrient intake, and performance. Poult. Sci. 91:537-549. https://doi.org/10.3382/ps.2011-01559

Walter, W. S., A. M. George, A. C. Elizabeth, \& D. W. Russel. 2018. SAS for Mixed Models: Introduction and Basic Applications. SAS Institute Inc., Cary, NC. 